\title{
UN SECURITY COUNCIL: The 'Frozen' Victory of the Great Powers
}

\author{
Sefer YILMAZ
}

\begin{abstract}
There exists a broad agreement that the Security Council (SC) is anachronistic, and it is in urgent need of reform. Despite various attempts which have been made to amend the current structure of the SC for the last half a century, none of these has yielded any considerable result yet. This paper will look at the SC from both change management and international relations (IR) theories perspective and argue that the structure of the SC actually reflects not just 40s' but also today's "balance of power", which will be corresponded with the "state of balance" or "equilibrium" concepts of change management, where both driving forces and the restraining forces seem to stand still in balance. This structure is so firmly 'frozen' that, no one has been able to "unfreeze" it in Lewin's words, in order to launch a successful change, up until today. It will be concluded that the failure of change initiatives of the SC and at large, the global order is only likely to be explained by taking into consideration both the assumptions of those realist theories and change management approaches together.
\end{abstract}

Keywords: International Relations, Change Management, International Organizations, IR Theories, Power Politics, Global Order.

\section{Introduction}

The contemporary international world order based upon the SC structure, still clearly reflects $40 \mathrm{~s}^{\prime}$ balance of power, even though this balance is argued to be changed con-

Sefer YILMAZ

Deputy Undersecretary

Ministry of EU Affairs, Turkey

E-mail: kimden1478@gmail.com

Conflict Studies Quarterly

Issue 29, October 2019, pp. 62-78

DOI:10.24193/csq.29.5

Published First Online: 04/10/2019 siderably, if not drastically. Should this situation be regarded as a shortcoming of the international system? Should it be deemed as a success of the founders of the UN and creators of the SC, or a failure of the member states who have been unable to come to an agreement to form a new global order since then? Or both? Is the structure of the SC reflecting $40 s^{\prime}$ balance of power really outdated or does it still mirror today's power politics? What causes enabled this structure 
to last more than 70 years? The answers to these questions will be expounded in this paper through IR theories and change management approaches.

This study will start with an overview of the general characteristics of the contemporary international order in terms of international organizations. It will ponder upon the arguments regarding the instrumental characteristics of the international organizations, particularly the UN. The nature of the Security Council (SC) will be discussed by taking into consideration the historical context through which the SC is created. Permanent membership and veto power although attracting too much criticism will be regarded as reflections of the balance of power of the time, in a realistic perspective.

In the following section, the current global world order moving around the UN will be evaluated with respect to the principles of realist thoughts. It will be argued that the global order configured short after World War II (WW2) through the mechanisms of the international organizations, particularly the SC, apparently reflects the realist presumptions. It also will be contended that it is those same realist assumptions, which account for the relative stability of this structure up until today.

In the third section, among various change management approaches, some of the most related works such as Lewin's (1951) 3-step model and Field Theory, Kotter's (1995) establishing a sense of urgency, Stacey's (2003) types of order-disorder, Burnes' (2004a) felt-need and Schein's (1996) survival anxiety will be cited.

In the fourth section, the failure of the $\mathrm{SC}$ reform will be explained together with both change management approaches and realist assumptions. The concept of "balance of power", which is located at the center of international relations discipline, will be corresponded with "state of equilibrium" of Lewin's (1951) classical model, which lies at the roots of change management approaches. It will be argued that only taking into consideration both those realist theories and change management approaches together, it is possible to explain the unchanging nature of the SC and at large, the global order.

In the end, we will conclude that the covenant which has been made between the great powers of WW2 and the founding states of the UN seems to be valid today. The monument put up by the great powers at that time, is still standing whether it is enjoyed or not, and a new one has not been agreed upon by the member states yet. This is because of either the failures of members states who have not been able to get on the same page, or the great powers of WW2 with their matchless success, who have been able to reach an extensive compromise on the peace, after a devastating warfare, which would not be attained that easy in the years ahead.

Eventually, it will be underscored that the great powers of the WW2 have been able to render their triumph immortality, at least for quite a long time, through constructing a "frozen" world order around the UN, particularly based on the SC, which would not be defrosted that easy. Therefore, it is argued in this paper that the SC should be regarded 
both the perpetual win of the realist theories after having been challenged rigorously time and time again and the permanent victory of those great powers of WW2.

\section{Contemporary world order and realist explanations}

Falk (1983) asserts that world order focuses on the way on which world nations can reduce the likelihood of international conflicts and create social and economic prosperity. This description reflects the very intention put forth in the UN Charter. The principal aims of the UN, as implied by its founding Charter are:

"to save succeeding generations from the scourge of war, to reaffirm faith in fundamental human rights, to establish conditions under which justice and respect for the obligations arising from treaties and other sources of international law can be maintained and to promote social progress and better standards of life in larger freedom" (UN, 1945: 2).

However, although these declarations of will produce hope for the future of international society at first glance, there exist also arguments on the opposite side contending that the current international order is intentionally designed as an instrument to strengthen the hegemony of the great powers from the very beginning. According to some, powerful states create such kind of ordering mechanisms purposely to achieve their common goals (Haggard \& Simmons, 1987). Keohane (2002) was among those, who asserted that the hegemon states create ordering mechanisms, which help them achieve their goals, often with the least cost than they could do without such mechanisms. Mearsheimer (1995) was another prominent scholar who believed that international institutions like the UN and particularly the SC serve a great extent to the benefits of great powers. According to Mazarr, Priebe, Radin and Astrid (2016), what is referred to as the "international order" is the global order shaped mostly by the United States (US), on the basis of international institutions, after the WW2. Yet, building an international order for pursuing its own goals, has argued to be a formal program of the US foreign policy since 40s (Patrick, 2009). Brooks and Wohlforth (2009) maintained that it would be much harder for the US to promote its strategic interests worldwide if it did not invest in international organizations. Hence, a report to the National Security Council of US on April 12, 1950, set forth the logic underlying behind the US strategy of establishing a world order based on American values. In the report, it is revealed that the US must seek to create a world society with its allies (Executive Secretary, 1950). Obama was among those who articulated this vision in the years 2000s. He forthrightly admitted that:

"In the wake of the WW2, it was America that largely built a system of international institutions that carried us through the Cold War. Leaders like Harry Truman and George Marshall knew that instead of constraining our power, these institutions magnified it" (Obama, 2007). 
This debate comes up for discussion the motivations through which international organizations have been created. Did the impulse to create international organizations stem from the collective interests of the member states of those organizations or from the intentions of those powerful states who are striving to increase their significance in the balance of power. International organizations, which come to life shortly after the WW2 draw special attention at this point.

In the second half of the twentieth century, the US launched a new global order, based on a serious of international organizations through which it will be able to control world politics more easily. For instance, the UN was told to have been created for maintaining peace and prosperity and the Bretton Woods system for regulating global transactions (Fontaine \& Kliman, 2013). The US is argued to dominate not just the decision-making mechanisms but also the functioning ways of those organizations (Rather \& Jose, 2015).

The Charter of the UN was signed in June 1945 and the UN was established as an international organization in October 1945 (Conforti, 2005). Among the participated fifty-one states, 35 states were argued to be closely related to the US in one way or another (Luck, 2005). Just this data alone can imply the balance of power prevailed at the time when the UN is created.

The need to accept the realities of power politics is argued to be reflected at the SC and the equality of the member states is told to be reflected in the General Assembly (Heywood, 2011). Wilcox (1945) argued that the SC operationalized itself by allocating permanent seats and veto to the great powers of the time. It was supposed that the most significant reason for the League's failure was its inability to enforce its decisions and the SC was regarded as the main instrument to overcome the impotency of the League of Nations with the privileges provided for its permanent five members (P5) (Hilderbrand, 1990). Therefore, while on one hand structuring world security on a similar type of institution as the League of Nations, the Charter of the UN provided the SC with significant executive power to be able to uphold the world peace (Russell, 1958).

Thus, the SC was given not just primary responsibility but also the authority for the maintenance of international peace and security. According to Article 39 of the UN charter, the SC:

"... shall determine the existence of any threat to the peace, breach of the peace, or act of aggression and shall make recommendations, or decide what measures shall be taken in accordance with Articles 41 and 42, to maintain or restore international peace and security" (UN, 1945: Art. 39).

The SC is apparently the most powerful organ of the whole global order, with the authority to take coercive and binding decisions and actions to maintain and preserve international peace and security. SC's decisions have the authority of international law (Butler, 2012) through which it can impose blockades and authorize the use of armed 
forces (Gould \& Rablen, 2017). It has the right to act on behalf of the members of the UN:

"In order to ensure prompt and effective action by the United Nations, its Members confer on the Security Council primary responsibility for the maintenance of international peace and security, and agree that in carrying out its duties under this responsibility the Security Council acts on their behalf" (UN, 1945: Art. 24).

All the founders of the UN agreed in advance to accept and implement the decisions of the SC in accordance with the Charter (UN, 1945: Art.25). The members joined later to the UN are also deemed to be admitted complying with the charter provisions fully.

The Council consists of fifteen members, five of whom are permanent members while other tens are elected non-permanent members with two-year terms (UN, 1945: Art.23). Decisions are being taken at the Council with at least nine out of fifteen member's affirmative votes in addition to "concurring votes of the P5" (UN, 1945: Art.27). Five members of the General assembly were granted privileged powers at the SC by the Charter. These five states were the US, the USSR, the UK, China and France, often referred to as the "P5" (Butler, 2012). It is argued that because of the heavy responsibility rested on their shoulders, those states provided with an exceptional position at the SC with permanent seats (UN, 1945: Art.23) and veto power (UN, 1945: Art.27) which were interpreted later, as the solid hegemony of great powers over the UN. Bosco (2009) commented that the great powers' intention to dominate over the new organization was embodied in the veto. With this provision, the SC provided its permanent members with even greater protection (Wouters \& Ruys, 2005). This power was so essential that Roosevelt's Secretary of State Cordell Hull told the Senate in those days that "the veto provision was an absolute condition for the US' participation in the UN" (Eban, 1995).

Thus, SC became a "council of the victorious" in Alger's words (1996, p. 350). This picture was obviously the reflection of power politics prevailed at the time and was to be continued for an unprecedented period. P5, who by virtue of being the victorious powers at the end of the WW2 as military, also succeeded to allot to themselves this privileged position politically. Therefore, the SC could be regarded as a political victory of the P5, which generated much stronger and long-lasting implications for them than their military triumph.

As an extension of the above discussion about the instrumental characteristic of international institutions, several authors have argued that the SC was an instrument which is utilized to legitimate and support the policies and actions of a limited number of powerful states (Claude, 1996, Berdal, 2003, Hurd, 2007, Cronin, 2008). Supporting this hypothesis, Claude (1996) claimed that states provide political capital based on the approval of the SC for their own actions. Particularly regarding the actions of the US with respect to the UN, there is much more criticism. For instance, Luck draws at- 
tention to the US's growing disposition to move alone free from the SC decisions (Luck, 2005). One step further, it is also argued that the SC is "abused to legitimize US direct or indirect military interventions around the world on a number of occasions" (Rather \& Jose, 2015, p. 53).

Supporters of liberalism argued that states sharing liberal values had no reason for going to war with one another (Grewal, 2016; McGlinchey, Walters and Scheinpflug, 2017). In a liberal order, states violating international norms and agreements face considerable costs (Meiser, 2017). Moving ahead from the liberal assumptions, League of Nations was created for the purpose of maintaining peace worldwide. It was expected that under the umbrella of international institutions, which were erected on liberal principles, there would be no significant conflicts leading wars. However, things went wrong. The League which was established with those liberal ideas, could not be able to perform as expected and collapsed with the outbreak of the WW2. Therefore, this development harmed deeply the belief in liberal assumptions and later, realism emerged with an argument to explain the presence of war (McGlinchey, Walters and Scheinpflug, 2017).

Yet, on the contrary, some argued that liberalism was reborn short after the WW2 with the international order, which was structured on the premise of liberal thoughts. The nature of this global order with its international organizations and norms are argued to be structured to restrain the violent power of states (Meiser, 2017). From this point of view, the UN stands out at the center of this liberal system. To some extent, this could be deemed sensible. However, looking inside the structure and functioning of the UN and particularly its executive organ the SC, it can apparently be observed that both the structure and the functioning of the SC reflect the characteristics of balance of power, which realist thought put forth. From this point forward, we will try to assess from which certain aspects the SC corresponds with the assumptions of the realist school.

Realism posits that states struggle for survival and dominance against all others in an orderless and anarchic environment, namely international structure. In such a circumstance, there seem to be two ways of action for the states to survive: States can either rely on only themselves (Antunes \& Camisao, 2017) or they can survive being a part of a hegemon authority. However, Grewal contended that there was a third way of action for the states to survive which was to establish an overarching coercive authority or global hegemon (Grewal, 2016). This recalls Hobbes's reputed social contract. Hobbes argued that humans can only escape from living in an orderless state of nature, which he perceived as a war of all against all, by constructing a civil sovereign (Hobbes, 1651b). The order comes to light through this general consent is what Hobbes defined as a "commonwealth by institution" or simply a "commonwealth" (Hobbes, 1651b).

Airaksinen and Bertman (1989) put forth that "World Government is justified on Hobbesian principles" despite Hobbes did not articulate such an idea of global order. This approach moves from the presumption that states in anarchical state of nature, 
accepted to fall under the hegemony of an international structure with their free will, in order to gain relative security (Grewal, 2016: 670). The international structure emerged through this presumption, is argued to constrain states from taking certain violent actions one another (Waltz, 1991). This structure could easily coincide with the UN system.

According to Hobbes, what creates an instituted commonwealth is that "each of its members, in a quiet mind gives consent to its construction", taking into consideration of advantages and disadvantages both (Hobbes, 1951b). This is what happened during the establishment of the UN. In 1945, fifty-one founding states, being totally aware of the advantages and disadvantages of the new organization, gave their consent to the establishment of the UN. The members of the UN have agreed that the SC act on their behalf and carry out the decisions of the SC in advance by signing the UN Charter. As regulated in Article 24 (1) of the UN Charter (UN, 1945: Art.25):

"In order to ensure prompt and effective action by the United Nations, its Members confer on the Security Council primary responsibility for the maintenance of international peace and security, and agree that in carrying out its duties under this responsibility the Security Council acts on their behalf".

Waltz (1979) maintains that states will be unwilling to sign any agreement that put them in a worse situation relative to others. So why those founding states agreed to a hierarchical structure, which apparently put them into a lower position vis a vis the P5 states? The answer of this question lies behind the historical records of the WW2. It is because, the misery experienced by humanity during the devastating battles of the WW2 led states to give assent to the establishment of a hierarchical international structure, although putting them into a lower position, for the sake of relative security (Butler, 2012). As Morgenthau (1978) argues, international organizations are merely the reflection of states' power distribution at the time those organizations are created. Therefore, in order to be able to grasp the logic behind the creation of the hierarchical nature of the SC, it is of primary importance to understand the time when the UN was established. Because the Council had its roots in wartime, the victorious powers of that war were provided with special status (Plesch, 2008). Indeed, the P5 have not been granted this privilege based on their capabilities alone but because of their characteristics as being major victors of WW2 (Stephen, 2018).

From this point of view, "the SC might draw on a degree of relative legitimacy" (Fave, 1980, p. 955). This perceived legitimacy of the P5 derived from the war led those states to possess special rights and responsibilities in the new global order. This acknowledgment was tied to power by Brown (2004). "The only hope for the world is the agreement of the Great Powers," said explicitly Winston Churchill confirming power politics (Gilbert, 1986, p. 1170). Hence, at the San Francisco conference, the naturalness of a hierarchical international system was articulated loudly by the great powers and as a result, the privileges provided to the P5 were taken for granted by the majority of the 
founding states (Hurd, 2007). This brings Waltz's "jump on the bandwagon" to mind. He asserted that in hierarchic political orders, actors tend to jump on the bandwagon of a recent victor, in order to gain relative security (Waltz, 1979). It seems that the founding members of the UN preferred to jump on the bandwagon, despite their certain concerns, to feel relatively much more secure in the international structure.

Another related realistic argument articulated by Hobbes, which will be corresponded with the UN is about the concept of liberty. Hobbes argued that the insecurity experienced in the state of nature pushes individuals to transfer some of their natural liberties to the civil sovereign. This loss of natural liberty is compensated by the gain of security (Hobbes, 1651b). Bull (1977) explains states' limiting their own sovereignty with the sense of rational calculation that this renunciation will lead to secure their independence. These are the assumptions that reveal why the founding states gave their assent to the SC permanent seats and the veto power associated with those seats. States at that time, have been exhausted of successive devastating wars, wished to feel more secure at the cost of losing some of their, with Hobbes' words, natural liberties. In turn, they gained relative security and order in the international structure they live through. Hammarskjöld who was then Secretary-general ${ }^{1}$ of the UN articulated this mindset and situation in an eloquent way:

"The United Nations was not created to bring us to heaven, but in order to save us from hell".

Another striking argument was stated by the UK representative during the discussions of the UN Charter as:

"The unanimity of the great powers was a hard fact, but an inescapable one. The veto power was a means of preserving that unanimity, and far from being a menace to the small powers, it was their essential safeguard. Without that unanimity, all countries, large and small, would fall victims to the establishment of gigantic rival blocs which might clash in some future Armageddon. Cooperation among the great powers was the only escape from this peril, nothing was of comparable importance" (Butler, 2012, p. 29).

Indeed, there has never been experienced a war among the P5 for more than seventy years (Bosco, 2014). With respect to this relatively peaceful relationship, Hobbes explanation in the De Cive is meaningful:

"For the state of commonwealths towards each other is a natural state, i.e. a state of hostility. Even when the fighting between them stops, it should not be called Peace, but an intermission during which each watches the motion and

1 1953-1961. 
aspect of its enemy and gauges its security not on the basis of agreements but by the strength and designs of the adversary" (Hobbes, 1651a).

He craftily describes the situation in which the global powers, particularly the US and Russia at the SC, deal with each other in almost every instance of political discussion. This also consists a sample of what Mearsheimer (2010: 78) depicted as "the currency of international politics". He argued that "the great powers were trapped in an iron cage where they had little choice but to compete with each other for power if they hope to survive" (Mearsheimer, 2006).

As a consequence, the nature of the $\mathrm{SC}$ realistically reflects the balance of power of both 40 s and today. It is hard to agree that the balance of power has been drastically changed since 1945 and that today prevails totally different power politics. If that argument was sound, then the structure of the SC should have been changed. The SC did not change not because the $\mathrm{P} 5$ vetoed the change resolutions, but it is because the member states have not been able to reach an even just one novel agreement on reform consonant with the Charter, other than they reached in 1961.

The realist thought argues that the possibility of significant change in international structure is limited (Antunes \& Camisao, 2017). This relative state of equilibrium is called the "balance of power", in real politics. What is experiencing today in terms of the failures of reform at the SC, actually reflects this realist assumption. However, this is not to say that it is totally impossible to implement a change at the SC successfully. Rather, this means that the picture in front of us is a sheer reflection of today's balance of power. If the power politics changes, then this picture owed to the SC will also be changed.

\section{Related Change Management Approaches}

It is argued that the phenomenon of change in organizations has never been of great importance than today's world (Kotter, 1996; Balogun \& Hope Hailey, 2004). In other words, the phenomenon of change is gaining speed at a great pace and occupying every aspect of our daily lives and institutions more and more. Kanter (1999) points out this reality as "business has never been conducted on such a global collaborative scale". Burnes (2004a) establishes that, change has become an inextricable requirement of organizations. Graetz (2000) asserts that in the face of ever-increasing developments, the primary mission for management today should be regarded as leading organizational change. Kanter, (1999) suggests that organizational change efforts to be reconsidered as doing business becomes more complex.

However, despite the emphasis underlined by a countless number of authors, it is reported that the failure rate of organizational change initiatives had reached almost up to 70 percent (Balogun \& Hope Hailey, 2004; Kotter, 2008; Hughes, 2011). Many scholars have been investigating the root causes of this high rate of failure from various aspects 
for years. For example, Kotter (1995) identified eight reasons, why change efforts failed, first of which was being unable to establish a sense of urgency. Armstrong (2006) supports this presumption by asserting that an awareness of the need for change is the start of the whole change process. Cummings \& Worley (2003) argued that organization members do not support change initiatives "unless they are convinced against the status quo". Stacey (2003) sets forth three types of concept regarding order and disorder for the organizations: the state of stable equilibrium, explosive instability, and bounded instability. He claims that the organizations can transform themselves in order to survive in face of ever-changing circumstances, only under the state of bounded instability.

Lewin's (1951) three-step change model is regarded as one of the oldest approaches describing the organizational change process. He maintained that the stability of organizational behaviors was based on a "quasi-stationary equilibrium" (Burnes, 2004b). He takes this relatively stable situation as somewhat "frozen" one. He argues that this frozen equilibrium needs to be unfrozen and the old behaviors have to be discarded first before any new set of behavior can be adopted successfully. Another fundamental contribution Lewin (1946: 240) made to the literature is the concept of "Field Theory". He puts forth that the status quo is maintained by certain driving and restraining forces within the field in which mutually interdependent dynamics coexist. He asserts that only with a perception of those forces, it would be possible to determine what forces need to be diminished or strengthened in order to unfreeze the equilibrium and bring about change (Burnes, 2004b).

Moving forward from Lewin's (1951) work, Burnes (2004a) stipulates that in order to be successful in organizational change attempts, there has to be a "felt-need", which is an individual's inner realization that change is necessary. Regarding unfreezing, Schein (1996) brings forward that to be committed to change, members of the organization must adopt the "disconfirming information", which leads them to feel a kind of "survival anxiety". This is the feeling that if they are not committed to change, they will highly likely fail to meet their needs. Then he puts forth that unless sufficient "psychological safety" is created, the disconfirming information will not be able to lead the organization members to survival anxiety, and therefore, no change will take place (Schein, 1996).

\section{Discussion and conclusion}

Since its foundation, the $\mathrm{SC}$ has attracted countless number of criticisms. Though the Council has become a much more prominent security actor influencing the world politics considerably, it is still prone to similar criticisms as before. Some asserted that the SC did not meet the needs of the contemporary world, because of the Council's decreasing legitimacy and effectiveness. Others pointed out to the problem of representation and democracy at the SC, which is argued to be inconsistent with the Charter and principles of the UN. However, most of the criticism leveled at the SC were regarding the 
permanent membership and the veto power provided to the P5. It is contended that these privileges were, to some extent, instrumental for keeping the great powers of WW2 in line with the new organization. It is also argued that the world has changed significantly, if not drastically, and the balance of power affected the configuration of the $\mathrm{SC}$ is no longer alive. Those holding this view demand the SC to be updated to today's global power distribution.

However, despite various efforts which have been exerted particularly for the last three decades, proposals regarding the reform of the SC have proved fruitless. This disappointing picture led many to blame the veto power to be the major or even only impediment on the way to reform. However, this was not the case. Contrary to the conventional presumption, none of the change proposals has been able to proceed up to the approval of P5. According to Article 108 of the UN Charter, before submitted to the member governments for ratification, change initiatives need attaining a two-thirds majority in the General Assembly. However, this quantity of majority has not been met yet for any of the change proposals. There does not exist any example, in which the P5 or any member of the P5 has blockaded a resolution regarding the SC reform after majority consent is provided in the General Assembly. Therefore, the assumption which accused the P5 being a major obstruction on the way to SC reform does not seem evidential.

According to change management scholars, if members of the organization believe that in the current situation the organization does not need any change, then they will not support any organizational change attempts (Kotter, 1995; Schein, 1996; Burnes, 2004b; Armstrong, 2006; Resnick, 1993). Further, there is an extensive consensus in the change literature that if those affected from organizational changes, particularly the organization members, do not make any contribution to the change process, it will be hard to succeed in change attempts (Guth \& MacMillan, 1986; Schwahn \& Spady, 1998; Cummings \& Worley, 2003).

Cummings and Worley (2003) claim that because the future of change is uncertain and may concern people's coping abilities and competencies, members of the organization will not support change unless they are convinced against the status quo. Member states seem not to have been duly convinced against status que so far. One reason of this picture might be that they have not trust in their competencies and coping abilities by their own, in words of Cummings and Worley (2003). Another reason may be that they have not felt enough "survival anxiety", in the words of Schein (1996), which refers to the feelings that "if they do not change, they will fail to meet their needs". For one reason or another, it is obvious that most of the member states have not supported the change initiatives so far and they gave in the current global order and acknowledged the power politics hierarchy.

Therefore, while it was the general assent of the founding states which gave birth to the SC in the very beginning of the UN for the sake of their own securities, it is still the 
same consent, overt or covert, that enables the SC to survive. This is almost a similar covenant as Hobbes described between the man and the civil sovereign with "a quiet mind" (Hobbes, 1651b). If this was not the case, at least one of the change proposals which have been drafted for the last 30 years, should have gained the requisite support in the General Assembly. However, the required majority for changing the UN Charter has never been attained except the one experienced in 1961, despite various attempts have been made for the last three decades. Shepsle (1989) argues that institutional change occurs when a sufficient number of members are able to disrupt the institution. Moving this point forward, the SC has not experienced any fundamental change for the last fifty years because there were not sufficient number of members believing in change requirement and/or those members were not powerful enough to succeed in change the SC structure. Contrary, current structure of the SC reflecting the hegemony of great powers which is endorsed by the founding states, seems quite sustainable over time.

Today's balance of power, which is reflected obviously at the SC looks like somewhat a typical kind of "stable equilibrium". This is a situation, depicted by Stacey (2003), in which organizations have not the ability to transform themselves in order to keep pace with the ongoing demands and challenges and at last decease. It is as if the structure of the Council has been frozen and stabilized intentionally. In Parrat's (2014) words, the structure of the SC was an attempt to freeze world politics after the end of WW2. It seems the structure of the SC is so firmly frozen that, the very first step, in Lewin's (1951) 3-step model, "unfreezing" has not been achieved yet. This picture also depicts the state of "inertia" or "equilibrium" of the Force-Field Analysis (Lewin, 1958). Driving forces and the restraining forces seem to stand still in the balance. Organizational readiness of change has not been provided enough yet to alter this state of equilibrium. Organizational readiness points to the situation in which members of the organization are prepared to launch organizational change. Therefore, before trying to attempt any change initiative at the SC, first of all, organizational readiness for change, in other words "felt-need" should be created among the member states (Salasin \& Davis, 1977; Burnes, 2004a).

It is argued in this study, contrary to the conventional assumptions, that the SC with its peculiar nature of power politics, actually reflects the picture of not just the $40 \mathrm{~s}$, but it also mirrors today's balance of power. Members of the UN do not seem ready or willing enough to change this situation. It is because of this reality, that the SC has been able to maintain its constancy up until today. This balance of power also corresponds with the "state of quasi-equilibrium" depicted in Lewin's (1951) force-field model, where driving and restraining forces of change stand in balance. This causes an inertia which impedes the organizational change. The international structure configured after the WW2 around the SC seems to have been so firmly frozen that no one has been able to unfreeze it until now. Therefore, the very first phase of Lewin's (1951) 3-step model, "unfreezing" has not been experienced yet. 
However, this picture also reveals that how an incredible work has been done by those great powers through being able to persuade and agree the founding states of the UN on the hierarchical characteristics of the SC at that time. In this study, it is argued that, this outcome is a sheer evidence supporting the presumptions of realist theories. Member states have renounced their natural liberties, in the words of Hobbes, and powers, by transferring them to a supreme authority, namely the UN and particularly the SC, for the sake of relative security. This covenant still appears to be valid today. Therefore, the realist thought to a great extent, if not completely, still stands the most prevailing school in explaining the nature and functioning of the SC. The characteristics and continuity of the SC as well as its wartime origins, constitute very clear and strong evidence for this hypothesis. To sum up, it is argued in this paper that;

1. The structure and the functioning of the SC clearly reflect the balance of power of both 40 s and to a certain extent, today.

2. This balance of power is compatible with the concept of "quasi-equilibrium" in Force-Field Theory, where driving and restraining forces of change are in balance.

3. This is the reason why none of the change initiatives of the SC has yielded any considerable result for the last 30 years.

4. It is not just the veto power the major obstacle on the way to reform. Rather, it is also those member states who have not been able to come to an agreement up until today.

5. This situation, both today and the very beginning of the UN, apparently consists of a covered assent, which Hobbes depicted more than three hundred years ago.

6. It is this general assent that resulted in the SC come to life and still survive.

7. Therefore, according to the change management literature, if the SC is to be reformed, then, first, member states should agree upon the change requirement of the SC and the way change will be implemented.

8. Thus, driving forces should outweigh restraining forces and accordingly, the current structure of the SC should start to unfreeze.

9. Only then it would be possible to change the structure of the SC successfully.

10. The victorious powers of the WW2 have been able to render their triumph immortality at least, for quite a long time through constructing and freezing a world order around the UN, particularly the SC.

11. Therefore, the SC should be regarded not just the perpetual win of the realist theories which still stands intact after having been challenged time and time again, but also the permanent victory of those great powers of WW2.

Finally, we must note that this paper should not be taken for an effort to legitimize the current global order and its concrete symbol, the SC. Contrarily, while on one hand trying to put forth a diagnostic explanation to the contemporary world order in a realistic perspective through change management approaches, this study attempts to make member states understand that the craft is not to allege the veto power or anything else as an excuse, but it is to be able to come into line with the other member states, 
without a moment's delay, in order to establish a new world order, prevailing first and foremost, equity and human dignity. If those two principals are embraced honestly at the UN, the other requisites for the global peace will stand up by itself.

\section{References:}

1. Airaksinen, T., \& Bertman, M. A. (1989). Hobbes: War Among Nations. Aldershot: Gower.

2. Alger, C. F. (1996). Thinking about the Future of the UN System. Global Governance, 2(3), 335-360.

3. Antunes, S., \& Camisão, I. (2017). Realism. In S. Mcglinchey, R. Walters and C. Scheinpflug (Eds.), International Relations Theory (pp.15-21). Bristol: E-International Relations Publishing.

4. Armstrong, M. (2006). A Handbook of Human Resource Management Practice. London: Kogan.

5. Balogun, J., \& Hope Hailey, V. (2004). Exploring Strategic Change. London: Prentice-Hall.

6. Berdal, M. (2003). The UN Security Council: Ineffective but Indispensable. Survival, 45(2), 7-30.

7. Bosco, D. (2009). Five to Rule Them All: The UN Security Council and the Making of the Modern World. New York: Oxford University Press.

8. Bosco, D. (2014). Assessing the UN Security Council: A Concert Perspective. Global Governance, 20, 545-561.

9. Brooks, S. G., \& Wohlforth, W. C. (2009). Reshaping the World Order. Foreign Affairs, March/April 2009, 88(2), 49-63.

10. Brown, C. (2004). Do Great Powers Have Great Responsibilities? Great Powers and Moral Agency. Global Society, 18(1), 5-19.

11. Bull, H. (1977). The Anarchical Society. London: Macmillan.

12. Burnes, B. (2004a). Kurt Lewin and the planned approach to change: A re-appraisal. Journal of Management Studies, 41(6), 977-1002.

13. Burnes, B. (2004b). Managing change: A strategic approach to organizational Dynamics (4th ed.). Harlow: Prentice-Hall.

14. Butler, R. AC. (2012). Reform of the United Nations Security Council. Penn State Journal of Law \& International Affairs, 1(1), 23-39.

15. Claude, I. L., Jr. (1996). Collective Legitimation as a Political Function of the United Nations. International Organization, 20(3), 367-379.

16. Conforti, B. (2005). The Law and the Practice of the United Nations. Leiden: Martinus Nijhoff Publishers.

17. Cronin, B. (2008). International consensus and the changing legal authority of the UN Security Council. In B. Cronin and I. Hurd (Eds.), The UN Security Council and the Politics of International Authority (pp. 57-79). New York: Routledge.

18. Cummings, T. G., \& Worley, C. G. (2003). Organization development and change. California: Melissa S. Acuna.

19. Eban, A. (1995). The U.N. Idea Revisited. Foreign Affairs, 74(5), 39-55. 
20. Executive Secretary. (1950). A Report to the National Security Council - NSC 68, April 12, President's Secretary's File, Truman Papers.

21. Falk, R. (1983). The End of World Order: Essays on Normative International Relations. New York and London: Holmes \& Meier.

22. Fave, R. L. D. (1980). The Meek Shall Not Inherit the Earth: Self-Evaluation and the Legitimacy of Stratification. American Sociological Review, 45(6), 955-971.

23. Fontaine, R., \& Kliman, D. M. (2013). International Order and Global Swing States. The Washington Quarterly, 36(1), 93-109.

24. Gilbert, M. (1986). Winston S. Churchill: Road to Victory, 1941-1945. Washington: RosettaBooks.

25. Gould, M., \& Rablen, M. D. (2017). Reform of the United Nations Security Council: Equity and Efficiency. Public Choice, 173(1), 145-168.

26. Graetz, F. (2000). Strategic change leadership. Management Decision, 38(8), 550562.

27. Grewal, D. S. (2016). The Domestic Analogy Revisited: Hobbes on International Order. Faculty Scholarship Series, 5029, 618-680.

28. Guth, W. D., \& MacMillan, I. C. (1986). Strategy implementation versus middle management self-interest. Strategic Management Journal, 7(4), 313-327.

29. Haggard, S., \& Simmons B. A. (1987). Theories of International Regimes. International Organization, 41(3), 491-517.

30. Heywood, A. (2011). Global politics. New York: Palgrave foundations.

31. Hilderbrand, R. C. (1990). Dumbarton Oaks: The Origins of the United Nations and the Search for Postwar Security. Chapel Hill: University of North Carolina Press.

32. Hobbes, T. (1651a). De Cive. London: J.C.

33. Hobbes, T. (1651b). Leviathan. Oxford: Clarendon.

34. Hughes, M. (2011). Do 70 percent of all organizational change initiatives really fail? Journal of Change Management, 11(4), 451-464.

35. Hurd, I. (2007). After Anarchy: Legitimacy and Power in the United Nations Security Council. Princeton: Princeton University Press.

36. Kanter, R. M. (1999). Change is everyone's job: Managing the extended enterprise in a globally connected World. Organizational Dynamics, 28(1), 7-23.

37. Keohane, R. 0. (2002). Power and Governance in a Partially Globalized World. London: Routledge.

38. Kotter, J. P. (1995). Leading change: Why transformation efforts fail. Harvard Business Review, 73(2), 59-67.

39. Kotter, J. P. (1996). Leading Change. Boston: Harvard Business School Press.

40. Kotter, J. P. (2008). A Sense of Urgency. Boston: Harvard Business Press.

41. Lewin, K. (1946). Action research and minority problems. In G. W. Lewin (Ed.), Resolving Social Conflict, Selected Papers on Group Dynamic (pp. 143-152). London: Harper \& Row.

42. Lewin, K. (1951). Field Theory in Social Science: Selected Theoretical Papers. New York: Harper \& Row. 
43. Lewin, K. (1958). Group Decision and Social Change. In E.E. Maccoby, T.M. Newcomb and E.L. Hartley (Eds), Reading in Social Psychology (pp. 197-211). New York: Holt, Rinehart and Winston.

44. Luck, E. C. (2005). Reforming the United Nations: Lessons from a History of Progress. In P.F. Diehl (Ed.), The Politics of Global Governance: International Organizations in an Interdependent World (445-483), (pp. 381-421). Colorado: Lynne Rienner Publishers.

45. Mazarr, M. J., Priebe, M., Radin, A., \& Astrid S. C. (2016). Understanding the Current International Order. Santa Monica: RAND Corporation.

46. McGlinchey, S., Walters, R., \& Scheinpflug C. (Eds.). (2017). International Relations Theory, Bristol: E-International Relations Publishing.

47. Mearsheimer, J. J. (1995). The False Promise of International Institutions. International Security, 19(3), 5-49.

48. Mearsheimer, J. J. (2006). Structural Realism. Available at: http://mearsheimer.uchica go.edu/pdfs/StructuralRealism.pdf, (Accessed: 19.10.2018).

49. Mearsheimer, J. J. (2010). Structural Realism. In T. Dunne, M. Kurki and S. Smith (Eds.), International Relations Theories: Discipline and Diversity, 2nd ed., (pp. 77-94). Oxford: Oxford University Press.

50. Meiser, J. W. (2017). Liberalism. In S. McGlinchey, R. Walters and C. Scheinpflug (Eds). 2017 International Relations Theory, (pp. 22-27). Bristol: E-International Relations Publishing.

51. Morgenthau, H. J. (1978). Politics among Nations. New York: Knopf Press.

52. Obama, B. (2007, April 24). Remarks, The Chicago Council on Global Affairs, Chicago, Illinois, April 24, 2007, Available at: http://www.realclearpolitics.com/articles/2007/ 04/remarks_of_senator_barack_obam.html, (Accessed: 04.11.2018).

53. Parrat, C. F. (2014). International Organization in International Society: UN Reform from an English School Perspective. International Organization in International Society, 5(2), 7-21.

54. Patrick, S. (2009). The Best Laid Plans: The Origins of American Multilateralism and the Dawn of the Cold War. Lanham: Rowman and Littlefield.

55. Plesch, D. (2008). How the United Nations Beat Hitler and Prepared the Peace. Global Society, 22(1), 137-158.

56. Rather, M. A., \& Jose, K. (2015). United Nations and the Us Hegemony in the Post- Cold War World Order. International Journal of Peace and Conflict Studies, 2(4), 53-60.

57. Resnick, H. (1993). Managing organizational change: a primer for consultants and managers. In R. T. Golembiewski (Ed.), Handbook of Organizational Consultation (pp. 621-626). New York: Marcel Dekker.

58. Russell, R. B. (1958). A History of the United States Charter: The Role of the Unites States 1940-1945. Washington DC: Brookings Institution.

59. Salasin, S., \& Davis, H. R. (1977). Facilitating the utilization of evaluation: a rocky road. In I. Davidoff, M. Guttentag and J. Offutt (Eds.), Evaluating Community Mental Health Services: Principles and Practice, National Institute of Mental Health (pp. 428-443). Rockville: The Staff College. 
60. Schein, E. H. (1996). Kurt Lewin's change theory in the field and in the classroom: Notes toward a model of managed learning. Systems Practice, 9(1), 27-47.

61. Schwahn, C., \& Spady, W. (1998). Why change doesn't happen and how to make sure it does. Educational Leadership, 55(7), 45-47.

62. Shepsle, K. A. (1989). Studying institutions. Journal of Theoretical Politics, 1, 131-147.

63. Stacey, R. D. (2003). Strategic Management and Organizational Dynamics: The Challenge of Complexity. Harlow: FT/Prentice-Hall.

64. Stephen, M. D. (2018). “Legitimacy Deficits of International Organizations: Design, Drift and Decoupling at the UN Security Council", Cambridge Review of International Affairs, 31(1), pp. 96-121.

65. United Nations (1945). UN Charter. Available at: https://treaties.un.org/doc/publica tion/ctc/uncharter.pdf, (Accessed: 17.10.2018)

66. Waltz, K. N. (1979). Theory of International Politics. Reading, Chicago: Mass AddisonWesley Pub. Co.

67. Waltz, K. N. (1991). Realist Thought and Neo-Realist Theory. In R. L. Rothstein (Ed.), The Evolution of Theory in International Relations: Essays in Honor of William T. R. Fox (pp. 33-57). New York: Columbia University Press.

68. Wilcox, F. O. (1945). The Yalta Voting Formula. The American Political Science Review, 39(5), 869-898.

69. Wouters, J., \& Ruys, T. (2005). Security Council Reform: A New Veto for a New Century? Institute for International Law, K.U. Leuven, Egmont Papers. 